\title{
The Learning Styles and Multiple Intelligences of EFL College Students in Kuwait
}

\author{
Sulaiman Alrabah ${ }^{1}$, Shu-hua $\mathrm{Wu}^{1}$ \& Abdullah M. Alotaibi ${ }^{1}$ \\ ${ }^{1}$ Language Center, College of Business Studies, Public Authority for Applied Education and Training, Kuwait \\ Correspondence: Shu-hua Wu, Language Center, College of Business Studies, Public Authority for Applied \\ Education and Training, Kuwait. E-mail:wu104ohio@yahoo.com.tw
}

Received: October 15, 2017

doi:10.5539/ies.v11n3p38
Accepted: November 27, $2017 \quad$ Online Published: February 25, 2018

URL: https://doi.org/10.5539/ies.v11n3p38

\begin{abstract}
The study aimed to investigate the learning styles and multiple intelligences of English as foreign language (EFL) college-level students. "Convenience sampling" (Patton, 2015) was used to collect data from a population of 250 students enrolled in seven different academic departments at the College of Basic Education in Kuwait. The data elicitation instrument was derived from two standardized surveys: one on learning styles (Oxford, 1998) and one on multiple intelligences (Christison, 1998). Data collection utilized the Google Forms interface to facilitate participants' access and responses to survey items through their mobile phones. Data analysis identified the participants' general learning styles and multiple intelligences. The Microsoft Excel software program was used by the researchers to generate means, percentages, ranks, and standard deviations. Results indicated that while the participants' dominant learning styles were global, extroverted, hands-on, and visual, their dominant multiple intelligences were interpersonal, visual, and kinesthetic. Implications for pedagogy included recommendations to accommodate students' visual learning styles and multiple intelligences through the use of visual stimuli like PowerPoint presentations, charts, and graphs. In order to accommodate students' extraverted and hands on learning styles as well as their interpersonal and kinesthetic intelligences, the researchers recommended the use of group activities such as role plays, simulations, and debates. Implications for future research included conducting learning styles and multiple intelligences studies in other colleges in Kuwait.
\end{abstract}

Keywords: learning styles, multiple intelligences, English as a foreign language (EFL), individual differences, student-centered classrooms, teaching strategies, curriculum

\section{Introduction}

The past thirty years or so have witnessed a major change in the educational field in general and more specifically in foreign language pedagogy. This change was marked by the degree of emphasis educators were willing to give to the different components of the learning-teaching process. The student-centered classroom marked a shift in perspective from a traditional outlook that emphasized educational content and the teacher's role in imparting that content. The starting point of any course which was "what does the course content consist of and how it can be taught?" has changed into "how do students learn and what can the teacher do to facilitate the learning process?" This change in perspective has led educators to view the classroom not as a place where knowledge, of any kind, is taught, but as a place where the teacher can provide a language-rich environment in which student learning is facilitated. Within the context of the student-centered classroom, research interest in learners' individual differences has begun to expand (Ellis, 2012). Furthermore, research started to look for individual differences that can enhance the learning process in the classroom. Researchers on language learning have recognized the potential of learning styles and multiple intelligences in positively influencing classroom teaching (Reid, 1998). By accommodating the learning styles and multiple intelligences of our students, student learning of course content can be maximized because they will be potentially more receptive to our teaching strategies and modes of presentation. Thus, the theories of multiple intelligences (Christison, 2005; Gardner, 2006) and learning styles (Kolb, 2014; Oxford, 2003) have validated the existence of various ways of learning and of various types of intelligences. Learning styles were defined by Reid (1998) as "internally-based characteristics, often not perceived or consciously used by learners, for the intake and comprehension of new information" (p. ix). Moreover, Gardner (2006) defined intelligence as a person's ability to solve problems or create products that are valued in one or more cultural settings. He questioned the assumption that intelligence could be reduced to a single number or "IQ" score. 
Researchers have subsequently identified several general teaching practices that can accommodate students' learning styles and multiple intelligences such as instructional models that deviate from the traditional lecture format including visual presentations, site visits, and use of the Internet. Other practices included varying expectations for students' performance, from individual written formats to group work that includes writing and presentations. Moreover, new teaching practices included interpretation of theatrical, dance, musical, or artistic work, and performance of actual tasks at a work site, as well as choices that allow students to capitalize on their personal strengths and interests (Barr \& Tagg, 1995). These educational innovations were derived from research on learner-centered classrooms in Britain and North America where English is learned as a second language (ESL). The same studies showed that student achievements were enhanced as a result of those innovations.

The results of a number of studies that were conducted in EFL settings indicated that students' achievements were also enhanced when their learning styles and multiple intelligences were accommodated by college teachers. However, several other studies indicated that students' achievement levels suffered when their learning styles and multiple intelligences were not adequately accommodated by college teachers (e.g., Abbasian \& Shirazifard, 2016; Almigbal, 2015; Manee, Nadar, \& Jahrami, 2013; Samarakoon, Fernando, Rodrigo, \& Rajapakse, 2013; Winit-Watjana, Baraka, Mostafa, \& Aljaizani, 2015). The totality of studies conducted in EFL settings thus provided two distinct bodies of evidence. While some EFL colleges have accommodated their students' learning styles and multiple intelligences, other EFL colleges were dominated by teachers who preferred the traditional teacher-centered method of teaching that did not accommodate students' learning styles and multiple intelligences. There was a need, therefore, to discover EFL college students' learning styles and multiple intelligences in Kuwait. Findings from this research can inform college teachers about their students' dominant learning styles and multiple intelligences in order to accommodate them in the classroom. The purpose of the present study was, thus, to systematically investigate students' learning styles and multiple intelligences. Data collection and data analysis were conducted by the researchers to find answers for the following research questions:

1) What were the general profiles of EFL college students' learning styles?

2) What were the general profiles of EFL college students' multiple intelligences?

Implications for teaching drawn from this study may contribute to a more effective learning atmosphere for students, teachers, and curriculum-planners.

\section{Review of the Literature}

This review was organized into three sections. The first section explored the influence of learning styles and multiple intelligences in studies that promoted different applications of these theories in educational settings. The second section discussed studies that investigated the positive effects of accommodating students' learning styles and multiple intelligences on English proficiency. The third section focused on studies that investigated the negative effects of the mismatches between the teaching styles of college teachers and students' learning styles and multiple intelligences.

\subsection{Educational Applications}

According to Reid (1998) and Sauer (1998), the influence of the theories of learning styles and multiple intelligences within the field of education has led many teachers to adopt them as frameworks for the development of curriculum and classroom methodology. In a testimony to the influence of the theories of learning styles and multiple intelligences in educational settings, a number of researchers (e.g., Alhajri \& Al-Hunaiyyan, 2016; Alqatanani, 2017; Cox \& Tsai, 2013) have introduced applications that accommodated students' learning styles and multiple intelligences in different academic settings. First, Cox and Tsai (2013), from a North American university, explored the degree of student satisfaction with 3 different class formats that included $100 \%$ online, blended learning, and face-to-face classes. They based student satisfaction according to the learning styles of the students. The aim of the study was to measure students' degree of satisfaction with each course delivery type by establishing relationships between learners' learning styles and course types. They hypothesized that students would be most satisfied when the course delivery type matched their learning styles preferences. They found that the majority of students preferred to have face to face classes.

Second, Alhajri and Al-Hunaiyyan (2016) addressed the challenges of integrating learning styles into the design of hypermedia systems in education. They introduced an interface in computer-based learning (CBL) that attempted to accommodate the learning styles of both male and female students. The researchers aimed to incorporate learner characteristics such as gender, culture, and learning style in the design of both linear and non-linear computer-based learning (CBL) programs. They found gender-based differences in the ways participants preferred to use the interface. Female participants preferred to use non-linear programs while male participants preferred to 
use linear programs. Moreover, female participants were found to be more visual and filed-dependent than male participants who were found to be more verbal and field-independent than their female counterparts. Finally, Alqatanani (2017) investigated whether accommodating the multiple intelligences of students could contribute to their performance in critical reading classes. Alqatanani (2017) investigated the effects of a curriculum based on the theory of multiple intelligences on improving Jordanian EFL 10th grade students' critical reading skills in English. He conducted a quasi-experimental study in which the experimental group was exposed to multiple intelligences strategies in reading instruction while the control group was taught using the traditional method of teaching reading in English as a foreign language. Alqatanani found that the experimental group had outperformed the control group who were only exposed to traditional reading instruction. The researcher concluded that the experimental group that accommodated the multiple intelligences of the students helped them perform better than the students from the control group in mastering critical reading skills.

In conclusion, these studies showed the prospects of the application of learning styles and multiple intelligences theories into the educational field. These researchers have demonstrated the considerable potential of learning styles and multiple intelligences to benefit the educational process in computer technology, reading methodology, and classroom delivery types.

\subsection{Matches between Learning Styles, Multiple Intelligences, and English Proficiency}

A major assumption among educators is that when we accommodate students' learning styles and multiple intelligences in our lesson plans, our students will attain optimal achievement of the objectives of our courses. This assumption, however, was not subjected to close scrutiny by researchers and educators (e.g., Pashler, McDaniel, Rohrer, \& Bjork, 2008). In other words, no direct relationships were established between accommodating learning styles, multiple intelligences, and improved academic achievement. Researchers, therefore, have begun to investigate the relationships between learning styles, multiple intelligences, and English language proficiency. For example, Abbasian and Shirazifard (2016) investigated whether there were any significant correlations between students' multiple intelligences, learning styles, and their achievements in English language proficiency. They found a "significant" relationship between EFL learners' learning styles and English language proficiency and a "meaningful" relationship between EFL learners' multiple intelligences and English language proficiency. In other words, students whose learning styles and multiple intelligences were accommodated acquired English as a foreign language more successfully than other students who were taught in a traditional curriculum. Moreover, Glomo-Narzoles (2013) sought to determine the dominant multiple intelligence profiles and the motivations of 165 EFL students in Bahrain. Glomo-Narzoles argued that it was possible to motivate learners "through the use of tasks relating to the different intelligences" (p. 50). After identifying the types of multiple intelligences the students had, the researcher also sought to identify whether the types of motivation they had were either instrumental or integrative (Gardner, 1985; Gardner \& Tremblay, 1994). The Glomo-Narzoles' (2013) study showed that when students' multiple intelligences were accommodated in the English classroom, they became highly motivated to acquire the target language. Furthermore, Yassin (2015) used the Visual-Auditory-Reading-Kinesthetic (VARK) instrument to measure the learning styles of Gulf Co-operation Council (GCC) students in the English classes of two North American universities. Yassin (2015) found that due to the fact that the American teachers adjusted their teaching styles to accommodate the learning styles of GCC students, the students scored successfully on the Test of English as a Foreign Language (TOEFL) and performed well in the university setting. Moreover, Yeow, Min, Loh, and Blitz (2010) conducted a study on the learning styles, English proficiency, and assessment performance of medical students. They found that the students performed better when their learning styles were accommodated. In sum, these studies demonstrated that matching teaching styles to learning styles and multiple intelligences actually improved the language proficiency and test performances of both EFL and ESL students.

\subsection{Teaching-Learning Mismatches}

A growing body of evidence has suggested that a student's decision to major in a specialty area can cause a shift in his/her learning styles and multiple intelligences. This shift in students' learning styles may not match the teaching styles of EFL college teachers. The interaction between students' learning styles and multiple intelligences, on the one hand, and their specialty areas on the other, was investigated by a number of researchers. For example, Manee et al. (2013) investigated the learning style preferences of Allied Health Sciences students at Kuwait University. These researchers noted that "students' learning styles may evolve during their academic and practical training, and as they become socialized into the qualified health professional role" (p. 255). They found that the majority of students fell into the general learning style of "assimilator" (Kolb, 2014). This learning style is distinguished by a student's preference to be exposed to a sizable amount of new information and then learn or assimilate that information at a later stage. Consequently, the researchers suggested that educators at the College of Allied Health Sciences adopt a curriculum more-suited to the "assimilator" learning style of the majority of their students. The 
researchers also pointed out that Kuwaiti students had a tendency to be over-dependent on their teachers' explanations and lectures. Students, they suggested, must be trained to rely more on themselves in learning new material because, as the data analysis revealed, they will "assimilate" that new material as part of their assimilator learning style. Furthermore, Samarakoon et al. (2013) conducted a cross-sectional study in Sri Lanka's medical university hospital to track down the changes in the learning styles of three cohorts of pre-medical, medical, and post-medical students. They found that some shifts have occurred in the learning styles of post-medical students. They explained that these shifts may have been caused by the curriculum of post-graduate students which required them to think more independently than when they were still studying as pre-medical or medical students. A similar shift was not detected in the other cohorts of pre-medical and medical students. The researchers concluded that the curriculum of the medical school was didactic in nature and promoted a teacher-centered and subject-based classroom. However, when the same students went on to study as post-medical students, their learning styles shifted to cope with the changes in the curriculum. Moreover, Almigbal (2015) conducted a study on medical students in the kingdom of Saudi Arabia (KSA). According to Almigbal (2015), most Saudi medical students who preferred a single modality, preferred the "aural modality." Almigbal explained that the curriculum used in Saudi Arabian high schools promoted a teacher-centered and a lecture-based (listening) classroom. Moreover, the researcher found no relationship between students' learning style preferences and their academic achievements as reflected in their grade point averages (GPAs). Additionally, Winit-Watjana et al. (2015) conducted a study that compared between the motivations, learning styles, and program selections of 74 Pharmacy and 342 non-Pharmacy students during the preparatory year at the University of Dammam in Saudi Arabia. Findings indicated that there were no significant differences between the two groups in terms of their preferred learning styles. These findings also supported Almigbal (2015) in that the college curriculum needed to accommodate the students' learning styles preferences. Winit-Watjana et al. (2015) suggested that the mismatch between students' learning styles and the curriculum of the preparatory year could be rectified by gradually accommodating the learning preferences of their students. They recommended that "appropriate teaching modalities embrace didactic teaching (i.e., lectures and laboratory work), together with small-group discussions, role-plays, web-based learning and clinical practice" (p. 287). Finally, in a study of pre-service math teachers, Özgen, Tataroglu, and Alkan (2011) investigated the learning styles and multiple intelligences profiles of 243 pre-service math teachers studying at a university in Turkey. They found that the students' learning styles and multiple intelligences were not accommodated by the teaching styles of college teachers. The researchers suggested that a teacher who incorporates learning styles and multiple intelligences in his/her teaching strategies, curriculum planning, and assessment is better qualified to accommodate students' learning styles and multiple intelligences, and can, therefore, positively impact students' successful learning of mathematical content.

In conclusion, studies that investigated the interactions between university students' choices of majors and their learning styles and multiple intelligences have found that some colleges in EFL settings do not accommodate learners' learning styles and multiple intelligences in their curriculums. Therefore, they called for changes in the curriculum to a more interactive and student-centered classroom that accommodated the students' learning styles and multiple intelligences as they became socialized into their major disciplines. Thus, there was a need to conduct the present study to identify the learning styles and multiple intelligences of EFL college-level students in Kuwait.

\section{Methodology}

\subsection{Sampling and Participants}

The study targeted the learning styles and multiple intelligences of college-level EFL students in the College of Basic Education in Kuwait which has a student population of approximately twenty two thousand students. In order to gain access to the participants who were taking a general Freshman English course, "convenience sampling" (Patton, 2015) was employed to select students from a wide range of academic departments. A total of 250 students volunteered from seven different academic departments. They were solicited to anonymously respond to the online survey through Google Forms. Two of the researchers taught English courses at the English Language Unit of the college along with other English teachers. The head of the English Language Unit facilitated entry to other teachers' classrooms. He wrote a letter to encourage English teachers to join in the data collection effort. Survey data were collected from six English classes during the period from March till May, 2017. Students were solicited from these classes to volunteer to participate in the study and were informed about the purpose of the research. They were assured of anonymity and confidentiality and were requested to sign "informed consent" forms showing their agreement to participate in the study. The solicitation letters assured the participants that their names will be treated anonymously and that all the data will only be used for the purposes of the study. Finally, students were informed they were under no obligation to continue with the study, and that they were free to stop participating in the study whenever they chose to do so. 


\subsection{The Survey Instrument}

The researchers adopted a survey instrument by combining two standardized survey instruments: one by Oxford (2003) for measuring learning styles and another by Christison (2005) for measuring multiple intelligences. Both of the instruments have been validated for intermediate level EFL/ESL learners. In order to facilitate students' comprehension of survey items, both instruments were translated into Arabic and the final translation was refereed by an external reviewer. The survey utilized the Google Forms as an interface for students to provide their responses online at their own pace using their mobile phones.

Part one of the survey instrument consisted of five sections each relating to a distinct category of learning styles which Oxford (2003) organized into five distinct categories. According to Oxford (2003), section 1 "How I use my physical senses to study" was related to the way a learner prefers to use his/her senses to learn new material. Section 1 was devoted to the visual, auditory and hands-on "tactile" senses of perception. Section 2 "How I deal with other people," was related to whether a learner likes to study alone (i.e., introverted) or with others (i.e., extroverted). Section 3 "How I handle possibilities" distinguished between a person's uses of his/her intuition in decision-making as opposed to a person's use of analytic thinking and concrete-sequential organization. Section 4 "How I approach tasks" was related to whether a person likes a close-structured working environment or an open discovery-oriented mindset. Finally, section 5 "How I deal with ideas," was devoted to whether a learner prefers to use a global or analytic learning style. A global learner likes to get the main ideas in a written text, for example, and to communicate even if he/she doesn't know all the words or concepts in the text. An analytic person, by contrast, would focus more on details, logical analysis, and contrasts to understand the same text.

Part two of the survey instrument consisted of eight distinct categories of multiple intelligences (Christison, 2005). Linguistic-verbal intelligence refers to one's ability to process words and sentences to make or create meaning. Mathematical-logical intelligence refers to one's ability to process numbers and logical equations to understand calculations and complex mathematical questions. Visual intelligence is the ability to find one's way around an environment, to form mental images of physical reality. Musical intelligence is the ability to perceive and create pitch and rhythmic patterns. Bodily-kinesthetic intelligence is fine motor movement and athletic prowess. Interpersonal intelligence is the ability to understand others and how they may feel, and to interact effectively with them. Intrapersonal intelligence is the ability to understand oneself and to develop a sense of self-identity. Finally, naturalist intelligence is sensitivity to nature, natural objects, and natural phenomena.

Thus, the present study was conducted using an instrument adopted from both Oxford (2003) and Christison (2005) in order to discover the learning styles and multiple intelligences of EFL college students in Kuwait. Findings form this research can guide curriculum change and improve learning conditions for EFL learners at the college level.

\subsection{Data Collection}

In order to identify the general profiles of learning styles and multiple intelligences of Kuwaiti EFL college students, data collection focused on distributing the survey on learning styles and multiple intelligences to elicit participants' responses online. The survey items were encoded by the researchers on Google Forms for easy access through the students' mobile phones. From March to May, 2017, the survey was made available for the students. Out of a total of 250 students, there were 14 non-respondents to the survey, and the respondent rate was $94.40 \%$ which resulted in a total of 236 respondents.

\subsection{Data Analysis}

In order to identify the general profiles of learning styles and multiple intelligences of the students, data analysis first focused on the calculation of each scored survey item by adding up the cumulative numbers for each survey item. After the items of the survey were scored, the points for each of the intelligences and learning styles were totaled for each student. This step was made possible by utilizing the Microsoft Excel software program. Excel was also used to generate the means, standard deviations, percentages and ranks for each of the learning styles and multiple intelligences of the students. Subsequently, data analysis identified the dominant learning styles based on the highest total scored within each category. When the totaled numbers of the two learning styles were close to each other, two learning styles within the same category were identified as equally dominant. Furthermore, the dominant multiple intelligences were identified based on the ranks of means and percentages of each intelligence. Finally, data analysis resulted in two tables with descriptive statistics. Table 1 displayed students' learning styles and Table 2 displayed students' multiple intelligences. 


\section{Results}

The results of the survey provided a general view into the general profiles of learning styles and multiple intelligences of the Kuwaiti students.

\subsection{Learning Styles}

Table 1 displays the Kuwaiti students' learning styles, and gives the means, standard deviations, percentages, and ranks of each of the learning styles in the survey instrument.

Table 1. The general learning styles profiles of the Kuwaiti students

\begin{tabular}{lcccc}
\hline \multirow{2}{*}{ Categories } & \multicolumn{4}{c}{ Item Responses } \\
\cline { 2 - 5 }$\underline{\text { Section 1 }}$ & Mean & SD & \% & Rank \\
Visual & 18.36 & 3.18 & 36.75 & $(1)$ \\
Auditory & 14.47 & 3.47 & 28.97 & $(3)$ \\
Hands-on & 17.13 & 4.04 & 34.29 & $(2)$ \\
Section 2 & & & & \\
Extroverted & 17.51 & 5.17 & 60.64 & $(1)$ \\
Introverted & 11.37 & 5.37 & 39.36 & $(2)$ \\
Section 3 & & & & \\
Intuitive & 19.65 & 5.18 & 50.68 & $(1)$ \\
Concrete-sequential & 19.12 & 4.44 & 49.32 & $(2)$ \\
Section 4 & & & & \\
Closure-oriented & 19.75 & 4.76 & 58.00 & $(1)$ \\
Open & 14.30 & 4.09 & 42.00 & $(2)$ \\
Section 5 & & & & \\
Global & 19.90 & 3.71 & 56.80 & $(1)$ \\
Analytic & 15.14 & 4.29 & 43.20 & $(2)$ \\
\hline
\end{tabular}

Data analysis revealed that the dominant learning styles of the participants were visual, hands-on, extroverted, intuitive, concrete-sequential, closure-oriented, and global. The means, standard deviations, and ranks in section 1 showed that Kuwaiti students had a strong preference for both visual and hands-on "tactile" learning styles. While $36.75 \%$ of the students favored visual learning styles and $34.29 \%$ of the students favored hands-on learning styles, only $28.97 \%$ of the students favored auditory learning styles. In addition to a visual learning style $(\mathrm{M}=18.36$, $\mathrm{SD}=3.18)$, Kuwaiti students showed a preference for hands-on learning $(\mathrm{M}=17.13, \mathrm{SD}=4.04)$, which meant that they not only could learn from visual stimuli, but also could benefit from doing projects, working with objects, and moving around the classroom such as doing presentations and simulations. Overall, Kuwaiti students did not show a strong preference for the auditory learning style $(\mathrm{M}=14.47, \mathrm{SD}=3.47)$. This meant that the lecture format found in most of their college classrooms did not accommodate their visual and hands-on learning styles. In section 2, a majority of the Kuwaiti students amounting to $60.64 \%$ demonstrated a greater preference for an extroverted learning style $(\mathrm{M}=17.51, \mathrm{SD}=5.17)$ than an introverted learning style $(\mathrm{M}=11.37, \mathrm{SD}=5.37)$ which was preferred by only $39.36 \%$ of the students. This meant that Kuwaiti students could enjoy a wide range of social and interactive tasks which are largely student-centered such as group work, games, conversations, discussions, debates, and role plays in a student-centered classroom that promoted group work. In section 3, Kuwaiti students scored almost equally on both intuitive $(\mathrm{M}=19.65, \mathrm{SD}=5.18)$ and concrete-sequential $(\mathrm{M}=19.12, \mathrm{SD}=4.44)$ learning styles which meant that they could switch modes easily from intuitive to concrete-sequential. In this section, $50.68 \%$ of the Kuwaiti students preferred using their intuitions in decision-making while $49.32 \%$ favored using analytical thinking and concrete-sequential organization. In section 4, a majority of the Kuwaiti students showed a preference for closure $(\mathrm{M}=19.75, \mathrm{SD}=4.76) .58 \%$ of the Kuwaiti students preferred to work in a close-structured working environment as opposed to $42 \%$ of the Kuwaiti students who preferred to work in an open discovery one. They preferred to be explicitly given step-by-step instructions on how to accomplish projects and perform tasks. Finally, in section 5, the Kuwaiti students showed a clear preference for a global learning style $(M=19.90, S D=3.71)$ which indicated that they preferred to get the main ideas and to communicate even if they didn't know all the words or concepts. An analytic person, by contrast, would focus more on details, logical analysis, and contrasts. In this section, $56.80 \%$ of the Kuwaiti students preferred to learn globally while $43.20 \%$ of the Kuwaiti students preferred analysis and deduction. 


\subsection{Multiple Intelligences}

Table 2 displays the general intelligences found in Kuwaiti students, with the means, percentages, ranks, and standard deviations for each of the intelligences.

Table 2. The general intelligences profiles of the Kuwaiti students

\begin{tabular}{lcccc}
\hline \multirow{2}{*}{ Categories } & \multicolumn{4}{c}{ Item Responses } \\
\cline { 2 - 5 } & Mean & SD & $\%$ & Rank \\
\hline Interpersonal & 8.82 & 2.06 & 15.78 & $(1)$ \\
Visual & 7.87 & 2.28 & 14.07 & $(2)$ \\
Kinesthetic & 7.45 & 1.99 & 13.33 & $(3)$ \\
Logical & 7.16 & 2.74 & 12.81 & $(4)$ \\
Linguistic & 7.07 & 2.08 & 12.65 & $(5)$ \\
Naturalist & 6.58 & 2.61 & 11.78 & $(6)$ \\
Intrapersonal & 5.89 & 2.27 & 10.53 & $(7)$ \\
Musical & 5.07 & 3.18 & 9.06 & $(8)$ \\
\hline
\end{tabular}

Data analysis revealed that the dominant intelligences among the participants were interpersonal, visual, and kinesthetic. This meant that the participants had the abilities to engage in social activities in the classroom such as group discussions (i.e., interpersonal intelligence) as well as learn from visual displays and PowerPoint presentations (i.e., visual intelligence). Moreover, they had the ability to engage in activities that demanded physical action like simulations, role plays, and debates (i.e., kinesthetic intelligence).

In Table 2, the Kuwaiti students showed a high score for interpersonal intelligence ( $\mathrm{M}=8.82, \mathrm{SD}=2.06)$, with visual intelligence $(\mathrm{M}=7.87, \mathrm{SD}=2.28)$ ranking second and kinesthetic intelligence $(\mathrm{M}=7.45, \mathrm{SD}=1.99)$ ranking third. While $15.78 \%$ of the participants displayed interpersonal intelligence which ranked the highest among all other intelligences, $14.07 \%$ of the participants displayed visual intelligence which ranked second and $13.33 \%$ of them displayed kinesthetic intelligence and ranked third among all other intelligences.

Table 2 also showed the less dominant intelligence types among the participants. Logical intelligence $(M=7.16$, $\mathrm{S}=2.74$ ) ranked fourth among the Kuwaiti students amounting to $12.81 \%$ of the participants. Linguistic intelligence ranked fifth among the Kuwaiti students which amounted to $12.65 \%$ of the participants. Naturalist intelligence $(\mathrm{M}=6.58, \mathrm{SD}=2.61)$ ranked sixth among the Kuwaiti students which amounted to $11.78 \%$ of the participants. Intrapersonal intelligence $(\mathrm{M}=5.89, \mathrm{~S}=2.27)$ ranked seventh among the Kuwaiti students which amounted to $10.53 \%$ of the participants. Finally, result showed Kuwaiti students' musical intelligence (M=5.07, $\mathrm{SD}=3.18$ ) ranked eighth which amounted to only $9.06 \%$ of the participants.

\subsection{Discussion}

The main aim of the study was to discover the profiles of learning styles and multiple intelligences among Kuwaiti EFL college students. Another aim of the data analysis was to determine the dominant learning styles and multiple intelligences of the students. The results of the data analysis showed that while the participants' dominant learning styles were global, extroverted, hands-on, and visual, their dominant multiple intelligences were interpersonal, visual, and kinesthetic. Implications for pedagogy included suggestions for classroom practice such as introducing visual stimuli like PowerPoint presentations, charts, and graphs to accommodate students' visual learning styles and intelligences. Role plays, debates, and simulations can be used to accommodate their extroverted and hands-on learning styles as well as their interpersonal and kinesthetic intelligences.

The literature concerning learning styles and multiple intelligences especially among EFL college students presented two distinct bodies of evidence. While some EFL colleges have accommodated their students' learning styles and multiple intelligences, other EFL colleges were dominated by teachers who preferred the traditional teacher-centered method of teaching that promoted a classroom environment that did not accommodate students' learning styles and multiple intelligences (e.g., Abbasian \& Shirazifard, 2016; Almigbal, 2015; Manee et al., 2013; Samarakoon et al., 2013; Winit-Watjana, et al., 2015). Data gathered from the present study showed that there is a mismatch between the students' learning styles and multiple intelligences and the preferred teaching styles of EFL college teachers in Kuwait. In addition to Manee et al. (2013), the present study provided fresh evidence on the majority of EFL college teachers in Kuwait as being teacher-centered. Therefore, college teachers are recommended to accommodate their students' learning styles and multiple intelligences in the classroom. This means the classroom experience has to take into account participants' visual orientations as well as their 
extroverted (i.e., sociable) tendencies, and hands-on sensory perceptions for the classroom environment to be a motivating one. Moreover, research findings indicated that for the college teachers to accommodate the participants in their classes, teachers need to incorporate activities that are more motivating to visually-oriented students (i.e., visual), who feel comfortable working in groups (i.e., interpersonal), and who like to have hands-on learning experiences (i.e., kinesthetic). Therefore, implementing recommendations for classroom teaching from this study may entail a gradual departure from a classroom where most instruction is performed solely by the teacher to a student-centered classroom where students can assume a more active role in the learning process.

\subsection{Conclusion}

Data analysis revealed that the dominant learning styles of the participants were visual, hands-on, extroverted, intuitive, concrete-sequential, closure-oriented, and global. Data analysis also revealed that the dominant intelligence types among the participants were interpersonal, visual, and kinesthetic. College teachers in Kuwait can accommodate their students' learning styles and multiple intelligences by introducing visual stimuli and discussion groups, role plays, debates, and presentations in the college classroom.

\section{Implications for Pedagogy}

Implications were consistent with the results of the study on the participants' dominant learning styles and multiple intelligences. First, the data analysis revealed that the dominant learning styles of the participants were visual, hands-on, extroverted, intuitive, concrete-sequential, closure-oriented, and global. This meant that EFL teachers needed to accommodate the participants' learning styles within the classroom context. For example, students with a visual learning style prefer to have teaching strategies that employ visual stimuli as part of the EFL lesson. A teacher can use visual demonstrations (e.g., charts, graphic displays, and PowerPoint presentations) to accommodate visually dominant learners. Furthermore, a hands-on learning style indicates learners who do not like to sit and listen to the teacher during the lesson. Rather, they like to move around the class in controlled group activities that require them to employ the sense of touch in the learning process. Moreover, extroverted learners are very similar to students who have an interpersonal intelligence type. These styles and intelligences indicate that students prefer group and pair work to individual activities. EFL teachers should employ student-centered teaching strategies to fully engage them in the learning process. Furthermore, the data analysis revealed that the participants were flexible in dealing with possibilities and problems. Sometimes they will provide an intuitive solution to a specific problem, and some other times they will be concrete and sequential in finding solutions, In such cases, a teacher needs to incorporate tasks and activities of both kinds sometimes engaging their intuitive learning styles, and some other times tapping into their concrete-sequential learning styles. Moreover, data analysis revealed that the participants had closure-oriented learning styles. The teacher should be able to accommodate these learning styles by providing activities and tasks in which a student is given clear instructions to follow at every step in order to complete the task. Finally, data analysis revealed that the participants' global learning styles were more dominant than their analytic learning styles. EFL teachers need to strike a balance in the classroom between encouraging language use and language analysis and activities that promote fluency and accuracy in learning English as a foreign language.

Second, the data analysis also revealed that the dominant intelligence types among the participants were interpersonal, visual, and kinesthetic. The teacher can accommodate students who have an interpersonal intelligence by introducing tasks and activities that require collaborative group work such as simulations, role-plays, and debates. Moreover, students who have a visual intelligence are similar to those who have a visual learning style. They both need visual stimuli to engage them in the learning process. Finally, students who have a kinesthetic intelligence are similar to those students who have a hands-on learning style. They both need to be engaged in activities that require physical action.

\section{Implications for Future Research}

Future research needs to be conducted to verify the results obtained from the present study. Due to the fact that the data were collected within a relatively short period of time and a sample consisting of only 250 participants, there is a need to conduct studies that will further investigate the learning styles and multiple intelligences of EFL college students in Kuwait. Future research can, therefore, focus on a larger sample of EFL college students in Kuwait. In order to emerge with a better classroom learning environment for EFL college students in Kuwait, it is of vital importance to identify students' learning styles and multiple intelligences to begin to accommodate their dominant learning styles and multiple intelligences by college teachers and the college curriculum at large. 


\section{References}

Abbasian, G., \& Shirazifard, H. (2016). Synthesizing EFL learners' traits: MI, learning styles and language proficiency. International Journal of Language Learning and Applied Linguistics World (IJLLALW), 11(3), 32-47.

Alhajri, R., \& Al-Hunaiyyan, A. H. (2016). Integrating learning style in the design of educational interfaces. Advances in Computer Science: An International Journal, 5(1), 124-131.

Almigbal, T. H. (2015). Relationship between the learning style preferences of medical students and academic achievement. Saudi medical journal, 36(3), 349-355. https://dx.doi.org/10.15537/smj.2015.3.10320

Alqatanani, A. K. (2017). Do Multiple Intelligences Improve EFL Students' Critical Reading Skills? Arab World English Journal, 8(1), 309-321. https://dx.doi.org/10.24093/awej/vol8no1.22

Barr, R. B., \& Tagg, J. (1995). From teaching to learning-A new paradigm for undergraduate education. Change: The Magazine of Higher Learning, 27(6), 12-26. https://doi.org/10.1080/00091383.1995.10544672

Christison, M. A. (2005). Multiple intelligences and language learning: A guidebook of theory, activities, inventories, and resources. Provo, UT: Alta Book Center Publishers.

Cox, S. M., \& Tsai, K. C. (2013). Exploratory examination of relationships between learning styles and learner satisfaction in different course delivery types. International Journal of Social Science Research, 1(1), 64-76. https://dx.doi.org/10.5296/ijssr.v1i1.4100

Ellis, R. (2012). Language teaching research and language pedagogy. West Sussex, UK: Wiley-Blackwell.

Gardner, H. (2006). Changing minds: The art and science of changing our own and other people's minds. Boston, MA: Harvard Business Review Press.

Gardner, R. C. (1985). Social psychology and second language learning: The role of attitude and motivation. London, England: Edward Arnold.

Gardner, R., C., \& Tremblay, P. F. (1994). On motivation, research agendas, and theoretical frameworks. Rowley, MA: Newbury House.

Glomo-Narzoles, D. T. (2013). Multiple intelligences and motivational orientations in learning EFL. ANGLISTICUM: International Journal of Literature, Linguistics \& Interdisciplinary Studies, 2(1), 49-56.

Glomo-Narzoles, D. T. (2015). Multiple Intelligences and Motivational Orientations in Learning EFL. ANGLISTICUM. Journal of the Association for Anglo-American Studies, 2(1), 49-56.

Hajhashemi, K., Ghombavani, F. P., \& Yazdi Amirkhiz, S. Y. (2011). The relationship between Iranian EFL high school students' multiple intelligence scores and their use of learning strategies. English Language Teaching, 4(3), 214-222. https://dx.doi.org/10.5539/elt.v4n3p214

Kolb, D. A. (2014). Experiential learning: Experience as the source of learning and development (2 $2^{\text {nd }}$ ed.). Upper Saddle River, NJ: FT Press.

Manee, F., Nadar, M., \& Jahrami, H. (2013). Learning styles of allied health sciences students at Kuwait University. International Journal of Therapy and Rehabilitation, 20(5), 255-259. https://doi.org/10.12968/ijtr.2013.20.5.255

Oxford, R. L. (2003). Language learning styles and strategies: An overview. Learning Styles \& Strategies/Oxford, GALA 2003. Retrieved from http://web.ntpu.edu.tw/ langauge/workshop/read2.pdf

Özgen, K., Tataroglu, B., \& Alkan, H. (2011). An examination of multiple intelligence domains and learning styles of pre-service mathematics teachers: Their reflections on mathematics education. Educational Research and Reviews, 6(2), 168-181. Retrieved from http://www.academicjournals.org/ERR

Pashler, H., McDaniel, M., Rohrer, D., Bjork, R. (2008). Learning styles: Concepts and evidence. Psychological Science in the Public Interest, 9(3), 105-119. https://dx.doi.org/10.1111/j.1539-6053.2009.01038.x

Patton, M. Q. (2015). Qualitative research and evaluation methods (4th ed.). Thousand Oaks, CA: Sage.

Reid, J. M. (1998). Understanding learning styles in the second language classroom. Upper Saddle River, NJ: Prentice Hall Regents.

Samarakoon, L., Fernando, T., Rodrigo, C., \& Rajapakse, S. (2013). Learning styles and approaches to learning among medical undergraduates and postgraduates. BMC Medical Education, 13(1), 42. https://dx.doi.org/10.1186/1472-6920-13-42 
Sauer, C. (1998). Developing a survey for Multiple Intelligences. In J. M. Reid (Ed.), Understanding learning styles in the second language classroom (pp. 100-106). Upper Saddle River, NJ: Prentice Hall Regents.

Shirazifard, H. (2016). Integrating EFL learners' traits: MI, learning strategies and language proficiency. Journal of Fundamental and Applied Sciences, 8(3S), 2278-2297. https://dx.doi.org/10.4314/jfas.v8i3s.348

Winit-Watjana, W., Baraka, M. A., Mostafa, A., \& Aljaizani, R. A. (2015). Assessment of motivation, learning styles and program selections of Saudi pharmacy and non-pharmacy candidates during the preparatory year. Pharmacy Education, 15(1), 281-289.

Yassin, B. (2015). The academic effects of learning styles on ESL students in intensive English language centers. Journal of ELT and Applied Linguistics (JELTAL), 3(1), 37-53.

Yeow, T., Min, T., Loh, L., \& Blitz, J. (2010). An investigation into the learning styles, English proficiency and assessment performance of medical students. International Journal of Science, Medicine and Education, 4(1), 7-13.

\section{Copyrights}

Copyright for this article is retained by the author(s), with first publication rights granted to the journal.

This is an open-access article distributed under the terms and conditions of the Creative Commons Attribution license (http://creativecommons.org/licenses/by/4.0/). 